\title{
Analysis of Employee Performance, Organization Culture, Work Satisfaction and Organization Commitment
}

\author{
Nyayu Siti Rachmaliya \\ Doctoral Program, Human Resource Management, Jakarta State University \\ Jl. Rawamangun Muka, RT.11/RW.14, Rawamangun, Jakarta Timur, 13220 \\ Tel: 62-878-7819-6865Ｅ-mail: nyayurahmalia@gmail.com
}

Hady Efendy (Corresponding Author)

Education Practice and Academic Consultant

Tel: 62-852-8900-7870 E-mail: efendy_hady@yahoo.co.id

Received: August 21, 2017 Accepted: September 18, 2017 Published: September 20, 2017

doi: 10.5296/hrr.v1i1.11740 URL: https://doi.org/10.5296/hrr.v1i1.11740

\begin{abstract}
The purpose of this study is to analyze the innovation of an organization's management, strategic factors that support organizational management, efforts made, relationships with human resource development and application to human resource development. This research is a qualitative research with content analysis method. The data source in this research are document of five international articles, data collection, data analysis up to the presentation of data adopting Huberman and Milles model. Level of management maturity, organizational culture concepts and organizational performance and Information Technology systems in service to support their management. The success of the institution in carrying out its vision and mission cannot be separated from the readiness of human resources and facilities available. Innovation of an organizational management, Strategic factors that support organizational management, efforts undertaken, relationships with human resource development and application to human resource development are all dependent on Information Technology (Computer Applications), reliability and skill of human resources in using the application.
\end{abstract}

Keywords: Organizational culture, Job satisfaction, Commitment organizational, Employee 
performance

\section{Introduction}

The large number of employees (labor) requires an organization to think about how to use and optimize the performance of its employees. This is because employees are one of the important assets needed by the organization to perform the production process. The problem that arises is how to produce employees who have optimal performance. Optimal employee performance is one of the target organizations to achieve high work productivity. Employee performance is the level of success of employees in carrying out their duties and responsibilities. Employee performance is generally influenced by two factors, namely internal and external factors (Ismail, 2006). Internal factors are factors that come from within the employees, which include job satisfaction and organizational commitment. While external factors are factors that come from outside the self-employee, which includes leadership, safety and safety, and organizational culture.

One of the external factors affecting employee performance is organizational culture. Organizational culture is a growing value within an organization, where the values are used to direct the behavior of members of the organization (Soedjono, 2005). Employee behavior is influenced by the environment where they work formed through the culture of the organization and the existence of culture within an organization is expected to improve employee performance.

Besides affecting the performance of the work, the organizational culture also has a close relationship with job satisfaction. Job satisfaction can be defined as a pleasant or unpleasant emotional state in which employees view their work (Handoko, 1998, Widodo, 2006). If the employee's perception of culture in an organization is accordance with the wishes of employee, then the employee will be satisfied with his work. Conversely, if the employee's perception of culture in an organization is not support to organization system, then employees are not satisfied with his work (Robbins \& Judge, 2008). Employees who are satisfied with their work and think of their job as something fun will have a good performance.

In addition to organizational culture and job satisfaction, another variable that affects employee performance is organizational commitment. Organizational commitment is a circumstance where an employee sides with a particular organization and its goals and wants to maintain membership within the organization (Robbins \& Judge, 2008). The commitment of an employee to organization can be an important instrument for improving the performance of the employee (Khan et al., 2010). Organizational commitment also has relevance to organizational culture. According to Robbins and Judge (2008), one specific outcome of a strong organizational culture is the declining rate of employee rotation. The harmony of goals achieved between employees and organizations through culture will build an organizational commitment within the employee.

Job satisfaction also has a close relationship with organizational commitment. Job satisfaction is the first aspect to be achieved before an employee has an organizational commitment, which, according to Gunlu et al. (2010), job satisfaction has a significant effect on organizational 
commitment. Thus, variables such as organizational culture, job satisfaction, and organizational commitment theoretically have a close relationship in affecting employee performance.

Theoretical relationships are supported by several empirical studies which also find that organizational culture, job satisfaction, and organizational commitment have a positive and significant impact on employee performance (e.g. Yousef (2002), McKinnon et al. (2003), Koesmono (2005); Samad (2005); Manetje and Martins (2009); Ojo (2009); Rose et al. (2009); and Gunlu et al. (2010)). But there are also some empirical studies that find that organizational culture, job satisfaction, and organizational commitment have no significant effect on employee performance (e.g. Crossman and Zaki (2003); Chang and Lee (2007); and Yiing and Ahmad (2009).

\section{Methodology}

In accordance with the problems and objectives proposed in this study is to obtain a general description of discovering the renewal of innovation, strategic factors, efforts undertaken, relevance to human resource management, and Applications on the improvement of Human Resources obtained from a description of five articles as data that have been published by other researchers on different international journal. This research is a research based on qualitative approach with content analysis method by using inductive procedure. The data obtained and analyzed are then grouped into pre-defined categories. Aspects of textual interpretation following research questions are incorporated into categories. The categories can be revised and converged simultaneously through the analytical process.

The purpose of content analysis is to find the depth of meaning that exists in the object under study. So this study will present a report containing data citations to describe the innovation of an organization's management, strategic factors that support organizational management, the efforts undertaken for the development of human resources and applying it in human resource development efforts.

The research procedure can be detailed as follows:

\subsection{Data and Data Resource}

\subsubsection{Data}

Data in this research is qualitative data that is in the form of document (five articles) with title: 1. K Pavithra and S. Kirubadevi. (2016). A study on performance analysis of selected it companies. International Journal of Commerce and Management Research. ISSN: 2455-1627. Volume 2; Issue 1; January 2016; Page No. 18-20.

2. Jannete Elisabeth Taroreha, A. L. Rantetampang and Agus Zainuric. (2017). The Relation between the Quality of Service and the Level of Satisfaction on Inpatients at Abepura Regional General Hospital. International Journal of Sciences: Basic and Applied Research (IJSBAR). ISSN 2307-4531 (Print \& Online) http://gssrr.org/index.php?journal=JournalOfBasicAndApplied. 


\section{1) Macrothink}

Human Resource Research

ISSN 1948-5441

2017, Vol. 1, No. 1

3. Oluwafemi Emmanuel IDOWU. (2017). Understanding Organizational Culture and Organizational Performance: Are They Two Sides of the Same Coin?". Journal of Management Research. ISSN 1941-899X 2017, Vol. 9, No. 1.

4. Beatrice Dinda, Patrick B.Ojera and Bulitia Godrick Mathews. (2016). Analysis of Quality Management Practices and Organizational Performance of Private Healthcare Facilities in Nairobi County, Kenya. International Journal of Novel Research in Marketing Management and Economics. ISSN 2394-7322. Vol. 3, Issue 3, pp: (115-125).

5. Samy S Abu Naser, Mazen J Al Shobaki and Youssef M Abu Amuna. (2016). Measuring Knowledge Management Maturity At HEI To Enhance Performance-An Empirical Study at Al-Azhar University In Palestine. International Journal of Commerce and Management Research. ISSN: 2455-1627, Volume 2; Issue 5; April 2016; Page No. 55-62.

The data studied relate to the innovation aspect of an organizational management, strategic factors that support organizational management, efforts undertaken, relationship with human resource development and application to human resource development.

\subsubsection{Data Source}

The data source is the subject of the study from which the data was obtained. In general, the source data is taken from two sources, namely primary data source or main data source and secondary data source or supporting data source. Secondary data sources, taken from manuscripts or documents from management articles.

\subsection{Data Collection Techniques and Procedures}

Data collected using inventory techniques, which search and collect some data include:

\subsubsection{Data Collection Procedures:}

1. The data based on the review five articles.

2. Data collection through interviews, observation and study documents/articles.

3. Recapitulation of data.

4. Read and study the literature, references relating to what issues will be researched so as to generate an answer related to innovation of an organization's management, strategic factors that support organizational management, efforts made, relationships with human resource development And application to human resource development.

5. Record and enter the data obtained from five different articles publishers into the data analysis, then analyzed so that the data obtained in accordance with the formulation of the problem and research objectives.

\subsubsection{Data Analysis Procedure}

Data analysis technique used in this research is by using interactive model of Milles and Huberman (1994) suggest that activity in qualitative data analysis is done interactively and continuously until complete, so that the data is saturated. Activities in data analysis include three components: data reduction, data presentation, and conclusion drawing. Milles and Huberman model analysis has three well-established components that are before, during, and 
after the implementation of data collection. So in analyzing this data carried out the steps as follows:

1. Read of data the article

2. Data Collection

The data collection stage is done by the researcher by collecting the supporting data contained in the research object. These data are data related to the innovation of an organization's management, strategic factors that support organizational management, efforts undertaken, relationships with human resource development and application to the development of human resources.

\section{Reduce Data}

Reduce data is the stage of removing data that is not required by researchers, such as data that includes innovation of an organization's management, strategic factors that support organizational management, efforts made, relationships with human resource development and application to development human resources but not in accordance with research focus. Through the data reduction phase all data from the collected research object will be selected according to the researcher's need for. Thus, data that are not in accordance with the focus of research is not used by researchers.

\section{Data Classification}

At the classification stage the researcher classifies the data according to the sub focus. Classification of data conducted by researchers is compiling data that have been found by researchers related to focus of the research.

\section{Analyze Documents}

The researcher analyzes the document based on the identification of the problem that has been formulated. In this activity the researcher uses the innovation of an organizational management, strategic factors that support organizational management, the efforts undertaken, the relationship with the development of human resources and application to human resource development. Researchers describe the innovations of an organization's management, strategic factors that support organizational management, efforts made, relationships with human resource development and application of human resource development based on standardized studies and suggestions of its application in an institution.

6. Presentation of Results

This research is presented by presenting data in the form of descriptions of the results of analysis in the form of a sentence. The description is a description of the problem formulation that is answered by the researchers in the form of description of research results.

7. Concluding Research Results

In the final activity of the research is to conclude the analysis result. Researchers present the results of an innovation analysis of organizational management, strategic factors that support organizational management, efforts undertaken, relationships with human resource development and application of human resource development that has been done by researchers using research work step. 


\subsubsection{Data Inspection and Validity}

Examination of the validity of data in a study is necessary. In the opinion of Sugiyono (2007), on qualitative research to obtain valid and reliable data tested is the data. The validity of data in qualitative research may depend on the wealth of information data obtained and or to the ability of the researcher's analysis of the collection of such information. According Sugiyono, that the credibility test data or trust to the data of qualitative research results, among others, can be done with extension of observation, triangulation, discussion with peers, analysis of negative cases, and member check.

Data validity techniques used in this research by:

1. Diligent observation of the data, diligent in analyzing always focused on the subject matter so as not far from the issues discussed. Perseverance of observation means seeking consistently with various ways in relation to the content analysis process. In this case, the researcher performs careful observational persistence in accordance with the sub focus of all research.

2. Adequacy of theory, in this case makes a solid description of the results of research. This description is expected to succeed in providing detailed explanations to increase the validity of the research results supported by the adequacy of the theory.

3. Checking to colleagues, doing question and answer to fellow researchers to obtain the accuracy of the results of the analysis.

4. Invite an expert or expert to review or discuss the results of research, conducted by way of confirming the results of data analysis to mentors as experts. The confirmation results can be used to improve the accuracy and reliability of the results of data analysis and conclusions of this study. Thus, analysis of possible data by the researcher can be reduced.

5. Extend time in analyzing to get accurate result of research

6. The researcher performs the procedure to check back all the research data. So the results can be accurate.

\section{Literature Review}

\subsection{Employee Performance}

Performance is the result of work in quality and quantity achieved by a person in carrying out tasks assigned to employee in accordance with predefined standards or criteria. Performance shows the level of success of employees in carrying out their duties and responsibilities. The higher the employee's performance, the overall organizational productivity will increase.

An employee will have a high level of performance if there is a match between work and ability. If it can be fulfilled, it will arise a sense of responsibility towards the work and willingness to participate in achieving organizational goals through the implementation of tasks to the fullest. Therefore, organizations need to pay attention to the management of human resources (employees) to produce high performance in order to improve overall organizational performance.

There are three factors that affect the performance of individual employees, namely: (1) the 
ability of individuals in carrying out the work; (2) the level of business conducted; and (3) organizational support (Mathis and Jackson, 2006). Employee performance can be improved if all three factors are present in the employee, and employee performance will decrease or decrease if one of these factors does not exist

\subsection{Organizational Culture}

Robbins and Judge (2008) define organizational culture as a shared system of meaning shared by members that differentiate the organization from other organizations. According to Robbins and Judge (2008) organizational culture represents a common perception of the members of the organization. It is therefore desirable that individuals of different backgrounds or at different levels within the organization can understand the organizational culture in the same sense.

Hofstede (1986, in Koesmono, 2005) states that culture is a variety of interactions of habitual characteristics that affect groups of people within their environment. In order for organizational culture to function optimally, organizational culture must be created, defended, and strengthened and introduced to employees through the socialization process (Nurtjahjani and Masreviastuti, 2007). Through this socialization, employees are introduced about the goals, strategies, values, and standards of organizational behavior as well as work-related information.

\subsection{Job Satisfaction}

By definition, job satisfaction is a positive attitude of employees to their work, which arises based on an assessment of the work situation (Robbins and Judge, 2008; Umam, 2010). Pleasant work situations can be formed if the nature and type of work to be done in accordance with the needs and values owned by employees. Thus, a satisfied employee prefers his work situation rather than a disgruntled employee, who does not like his work situation.

Job satisfaction perceived by employees is influenced by two factors, namely intrinsic factors and extrinsic factors (Johan, 2002). The intrinsic factor is a factor that comes from within the individual that every employee has taken since starting work in his workplace. While extrinsic factors are factors that come from outside the employees themselves, such as the physical condition of the work environment, interaction with other employees, payroll systems, and so forth. Meanwhile, according to Luthans (2006), there are five dimensions that affect job satisfaction, namely: the job itself, salary, promotion opportunities, supervision. Supervisor, and colleagues.

\subsection{Organizational Commitment}

Organizational members who are committed to their organization may develop a more positive view of the organization and are happy to spend extra energy on behalf of the organization (Anik \& Arifuddin, 2003). It shows that organizational commitment has more meaning than passive loyalty, but it involves an active relationship and an employee's desire to make a significant contribution to his organization.

According to Greenberg and Baron (1993, in Chairy, 2002), employees with high organizational commitment are more stable and more productive employees and ultimately 
more profitable for the organization. Mowday et al. (1982, in Chairy, 2002) suggests features of organizational commitment, namely: (1) strong beliefs as well as acceptance of organizational goals and values; (2) readiness to work hard; And (3) a strong desire to survive in the organization.

The benefits of this article are to discover the renewal of innovation, strategic factors, efforts undertaken, relevance to human resource management, and the Application of human resources improvement from five articles published by five different international journal.

So based on the background, problems, and benefits experienced in this article, the sub-focus of research is how innovation of an organization's management, strategic factors that support organizational management, efforts made, relationships with human resource development and application to development human Resources.

\subsection{Huberman and Milles Model}

Qualitative data analysis is a series of process of finding and compiling qualitative data obtained from interviews, observation records, and other materials systematically. This process aims to make data easy to understand and findings can be informed to others. The method of qualitative data analysis is done by organizing the data, elaborating it into small units, synthesizing it, arranging it into patterns, selecting and sorting out important and unimportant data, and finally concluding so that the conclusions are information that can be submitted to other people.

One of the most widely used qualitative data analysis techniques in scientific research such as thesis and his comrades follows the concept of Miles and Huberman. In the view of Miles and Huberman, the activity of qualitative data analysis is done interactively and continuously at each stage of the research until complete and saturated.

There are 3 stages of qualitative data analysis according to Miles and Huberman, namely data reduction, display, and conclusion / verification.

1. Data reduction

The purpose of data reduction is that we as researchers summarize, sort and select, and categorize the data we get from data sources through various data collection techniques that we do. In qualitative research, the main data are words and actions. In contrast to the research quantitative the main data in the form of numbers. Because action is part of the main data in qualitative research, the classroom action research (PTK) belongs to the qualitative research family.

2. Display data

Display data is to present qualitative data according to the form / pattern that can be done in the form of charts, graphs, brief descriptions, matrices, charts, and network. When the patterns found by researchers have been completed and supported by the data, then the pattern becomes a standard pattern which can then be presented in the final report of research such as thesis. The main data in qualitative research in the form of words and actions through the process of interviewing and observing human behavior, recorded through written recording and shooting 
in the form of photos. In this case, data obtained through written documents such as student work plan (RKS) and student's list of values during a certain period of position as the main data support.

3. Conclusion and verification

The last step in qualitative data analysis is the conclusion and verification. In Miles \& Huberman's view, drawing conclusions in qualitative data analysis is only part of a whole series of research processes. Verify the meaning of the researcher review or re-correct the records data he obtained and the meaning he did to the data.

Three steps of qualitative data analysis Miles and Huberman model above is enough to serve as a guide we choose in conducting qualitative data analysis. The conclusion in qualitative research is the answer or solution offered by the researcher on the formulation of predetermined problem. Conclusions can be new findings, clarify previously blurred objects, and solutions to specific problems.

\section{Results and Discussion}

1. K Pavithra and S Kirubadevi. (2016). A Study on Performance Analysis of Selected It Companies. International Journal of Commerce and Management Research. ISSN: 2455-1627. www.managejournal.com. Volume 2; Issue 1; January 2016; Page No. 18-20.

This article explains that information technology (IT) is a computer application and telecommunication equipment for storing, retrieving, transmitting and manipulating data, often in the context of business or other companies. This study was conducted to determine the performance and Position of profitability selected IT Sectors i.e. IBM, Microsoft, Oracle, SAP SE and Symantec. This study is based on secondary data collected from financial statements published from the official website of IT companies selected for five years from 2010-2011 to 2014-2017. Data have been analyzed using ratios and means of statistical means and correlation. On the basis of analysis of financial performance of selected IT companies have found that Oracle and Microsoft show remarkable financial performance when compared with other companies.

Based on this explanation, this article shows the information technology system in service to support their management. Innovation of an organization's management, strategic factors that support organizational management, efforts undertaken, relationships with human resource development and application to human resource development all depend on information technology, (Computer Applications), reliability and skill of human resources in using IBM, Microsoft, Oracle, SAP SE and Symantec applications is a key to success in institutional management, but on the other hand when a company relying on information technology systems with computer applications in a limited area of facilities and skilled human resources in computer applications, innovation and strategy and efforts to solve problems with IT become a very difficult condition.

2. Jannete Elisabeth Taroreha, A. L. Rantetampang, and Agus Zainuric. (2017). The Relation between the Quality of Service and the Level of Satisfaction on Inpatients at Abepura Regional General Hospital. International Journal of Sciences: Basic and Applied 
http://gssrr.org/index.php?journal=JournalOfBasicAndApplied.

The article explains that human resource management on the service side of the hospital institution still needs to improve the service of respondent's request, it means that innovation, strategic support and strategic efforts to optimize the service of the public as an institution that many put forward excellent service is still very far, In the cause of the development of trained and reliable human resources in service and utilization of facilities that support very limited. The article put forward the level of public satisfaction of the performance management of hospital employees is not optimal due to the low competence of human resources to run the hospital management of excellent service standards.

3. Oluwafemi Emmanuel IDOWU. (2017). Understanding Organizational Culture and Organizational Performance: Are They Two Sides of the Same Coin?. Journal of Management Research. ISSN 1941-899X 2017, Vol. 9, No. 1

The understanding of organizational culture is increasingly viewed as a necessary requirement for high performance in the organization. This is also suggestive that the culture of an organization may have a significant impact on the success of the organization. The term of organizational culture is used widely, however inappropriately and occasionally defining and using it incorrectly. While there is universal agreement that organizational culture exists and that it plays a crucial role in shaping behavior and performance in organizations, there is little consensus on what organizational culture is and how it impacts on organizational performance. Without a reasonable understanding of the concept of organization culture and its definition, we cannot understand its relationships with organizational performance. This paper explores the notion and the understanding of the concepts of organizational culture and organizational performance. If we can define and understand the concept of organizational culture, then we can understand how it can impact on organizational performance.

This article discusses ideas and understanding of organizational culture concepts and organizational performance. If we can define and understand the concept of organizational culture, then we can understand how it can have an effect on organizational performance, or Innovation of an organization's management. Strategic factors that support organizational management as well as efforts undertaken, relationships with human resource development as well as application to the development of human resources made a new thing or conduct further studies. But the weakness in this article is only limited to an abstract understanding of the concepts of organizational culture so that further research needs to be done to further explain the concepts of organizational culture into something that is easy to do by all stakeholder companies or institutions.

4. Beatrice Dinda, Patrick B.Ojera, and Bulitia Godrick Mathews. (2016). Analysis of Quality Management Practices and Organizational Performance of Private Healthcare Facilities in Nairobi County, Kenya. International Journal of Novel Research in Marketing Management and Economics. Vol. 3, Issue 3, ISSN 2394-7322. pp: (115-125).

The health sector contributes $2.5 \%$ of the GDP in Kenya. Private healthcare facilities control 
$43 \%$ of the health sector in Kenya. Private healthcare sector has a significant market share, approximately $50 \%$ in Sub -Saharan Africa. In Kenya, it contributes $22 \%$ of all health services. Despite the sector's contribution, its annual growth rate continues declining from $5.2 \%, 3.5 \%$ and $2.3 \%$ in 2008, 2009 and 2010 respectively. Healthcare is different from other industries and because of the complexity of the provider- patient relationship, the asymmetry of knowledge and patient vulnerability, proponents of value need to focus on quality. The study adopted correlational survey research design. The population was 52 chief operation managers of 52 private health facilities accredited by NHIF in Nairobi. Pilot results $(\mathrm{N}=10)$ revealed 51-item instrument reliability ranged between $\alpha=0.700$ and $\alpha=0.867$. Further, results revealed that only three dimensions of quality management practices namely: ICT ( $\beta=0.266$, $\mathrm{p}=0.001)$; process management $(\beta=0.329, \mathrm{p}=0.007)$ and top management support $(\beta=$ $0.192, p=0.037$ ) had positive significant effect on organizational performance. The study concluded that quality management practices (Information Communication Technology, Process Management, Top Management Support) were significant predictors of organizational performance; quality management practices is a critical antecedent of organizational performance in private healthcare facilities in Nairobi. Quality management practices $(\beta=0.162, p=0.000)$ has a positive effect on organizational performance. Recommendations were that facilities should continue enhancing and instituting effective quality management practices as these efforts improve organizational performance. The study provided a quality management framework that will aid healthcare policy makers in strengthening the relationship between quality of care and organizational performance.

The article concludes that quality management practices (Information Communication Technology, Process Management, and Top Management Support) are significant predictors of organizational performance; Quality management practices are an important antecedent of organizational performance at private health facilities in Nairobi. Quality management practices $(\beta=0.162, p=0,000)$ have a positive effect on organizational performance. Recommendation is that facilities should continuously improve and institutionalize quality management practices. Innovation of an organization's management, Strategic factors that support organizational management, efforts undertaken, relationships with human resource development and application to human resource development all depend on the use of information communication technology, process management and management support. Humans at facilities in Kenya are very satisfying to the public/users despite being known as a poor country, the advantages of this article are limited to seeing the relationship of the existence of IT to the level of public satisfaction, do not look at other sectors that also affect the standard of service and management of an ideal institution.

5. Samy S Abu Naser, Mazen J Al Shobaki, and Youssef M Abu Amuna. (2016). Measuring Knowledge Management Maturity at HEI to Enhance Performance-An Empirical Study at Al-Azhar University in Palestine. International Journal of Commerce and Management Research. ISSN: 2455-1627. www.managejournal.com Volume 2; Issue 5; April 2016; Page No. 55-62.

This paper aims to assess knowledge management maturity at higher educational institutions, to determine the most effecting variables on knowledge management that enhance the total 
performance of the organization. This study was applied on Al-Azhar University in Gaza District of Palestine. This paper depends on Asian productivity organization model that used to assess KM maturity. Second dimension assess high performance was developed by the authors. The controlled sample was (364). Several statistical tools were used for data analysis and hypotheses testing, including reliability correlation using Cronbach's Alpha, "ANOVA", simple linear regression and step wise regression. The overall findings of the current study suggest that KMM is suitable for measuring and lead to enhance high performance. KMM assessment shows that the university maturity level is in level three. Findings also support the main hypothesis and it is sub hypotheses. The most important factors effecting high performance are: Processes, KM leadership, People, KM Outcomes, and Knowledge Process. Furthermore the current study is unique by the virtue of its nature, scope and way of implied investigation, as it is the first study at in Palestine explores the status of KMM using the Asian productivity model.

The article aims to assess knowledge management maturity in higher education institutions, to determine the most influential variables on knowledge management that improve the overall performance of an organization. The research was applied to Al-Azhar University in the Gaza District of Palestine paper. The overall findings from this study indicate that KMM is suitable for measuring and leading to improved high performance. The KMM assessment indicates that the university level is due at level three. The findings also support the main hypothesis and it is sub hypotheses. The most important factors that affect high performance are: Process, KM leadership, People, KM Outcomes, and Process Knowledge. Furthermore this research is unique with the virtue of the nature, scope and manner of implied investigation, as it is the first study in in Palestine exploring the use of KMM status. Innovation of an organizational management, strategic factors that support organizational management, efforts made, relationships with human resource development and application of human resource development is limited to the understanding or concept of management maturity as a key to improve the performance of the organization or institution has not shown of causes and how management are applied in other areas that do not necessarily have the same cultural culture.

\section{Conclusion}

Based on the findings and discussion it can be concluded that the five articles shows the level of management maturity, organizational culture concepts and organizational performance and systems information technology in the service to support their management. The success of the institution in carrying out its vision and mission cannot be separated from the readiness of human resources and facilities available. Innovation of an organization's management, strategic factors that support organizational management, efforts undertaken, relationships with human resource development and application to human resource development all depend on information technology (computer applications), reliability and skill of human resources In using IBM, Microsoft, Oracle, SAP SE and Symantec applications is a key to success in institutional management, but on the other hand when a company relying on information technology systems with computer applications in a limited area of facilities and skilled human resources in computer applications then Innovation and strategy and efforts to solve problems with IT become a very difficult condition. So for the institutions in Indonesia 
can also apply the findings of some articles if the readiness of human resources that are reliable, trained, skilled and understand and able to apply in the behavior and culture in the organization so that management works well then the performance will go up as well.

\section{Policy Implication}

Based on the results of organizational culture analysis, job satisfaction, organizational commitment, and employee performance, the policy implications suggested in this research are:

1. Organizational culture variables in this study affect the job satisfaction, organizational commitment, and employee performance. The organizational culture has a considerable influence in determining employee performance. Based on these conditions, companies need to make efforts to strengthen and maintain an existing culture to improve employee performance, among others by:

a. Conduct a deeper socialization of the vision, mission, values, and regulations applicable in the company so that employees are able to understand their duties and responsibilities so that the implementation can run well in accordance with the direction and purpose of the company.

b. Involve employees in every activity of the company in order to build a good cooperation and mutual respect among employees and employees with superiors.

c. Provide an opportunity for every employee to interact to build mutual trust and openness among employees and employees with superiors.

2. Job satisfaction variables in this study affect the organizational commitment and employee performance. The job satisfaction has a considerable influence in determining organizational commitment. Based on these conditions, the company needs to make efforts to increase job satisfaction in order to increase commitment in each employee, among others by:

a. Establish compensation policy, career development, and promotion based on the competence and achievement achieved by employees.

b. Provide supportive facilities for employees to enable them to work properly.

c. Fostering good communication and relationships between superiors with employees and fellow co-workers so as to create a pleasant working conditions.

3. Organizational commitment variable in this research have an effect on employee performance. Based on these conditions, the company needs to make efforts to maintain existing commitments in each employee to improve their performance, among others by:

a. Provide an opportunity for every employee to improve skills related to the task being done, such as providing training for employees who have the potential to grow so that employees are encouraged to contribute according to their ability.

b. Provide support done by the supervisor in the form of guidance and support behavior.

\section{References}

Anik, S., \& Ariffudin. (2003). Analisis Pengaruh Komitmen Organisasi dan Keterlibatan 
Kerja terhadap Hubungan antara Etika Kerja Islam dengan Sikap Perubahan Organisasi, JAAI, $7(2), 159-182$.

Aydin, B., \& Adnan, C. (2009). The Role of Organizational Culture on Effectiveness. Ekonomika A Management, 3, 33-49.

Beatrice, D., Patrick, B. O., \& Bulitia, G. M. (2016). Analysis of Quality Management Practices and Organizational Performance of Private Healthcare Facilities in Nairobi County, Kenya. International Journal of Novel Research in Marketing Management and Economics, $3(3), 115-125$.

Chairy, L. S. (2002). Seputar Komitmen Organisasi. Paper yang Disampaikan dalam Acara Arisan Angkatan 1986 Fakultas Psikologi Universitas Indonesia Jakarta tanggal 8 September 2002 .

Chang, S-C., \& Ming-Shing, L. (2007). A Study on Relationship among leadership, Organizational Culture, the Operation of Learning Organization, and Employees Job Satisfaction. The Learning Organization, 14(2), 155-185. https://doi.org/10.1108/09696470710727014

Cooper, D. R., \& William, E. C. (1996). Metode Penelitian Bisnis. Edisi 5 Jilid 1, Jakarta: Erlangga.

Crossman, A., \& Bassem, A.-Z. (2003). Job Satisfaction and Employee Performance of Lebanese Banking Staff. Journal of Managerial Psychology, 18(4), 368-376. https://doi.org/10.1108/02683940310473118

Ganesan, S., \& Barton, A. W. (1996). The Impact of Staffing Policies on Retail Buyer Job Attitudes and Behaviors. Journal of Retailing, 72(1), 31-56. https://doi.org/10.1016/S0022-4359(96)90004-4

Gunlu, E., Mehmet, A., \& Nilufer, S. P. (2010). Job Satisfaction and Organizational Commitment of Hotel Managers in Turkey. International Journal of Contemporary Hospitality Management, 22(5), 693-717. https://doi.org/10.1108/09596111011053819

Hair, J. F. (1995). Multivariate Data Analysis. (4th Edition). Prentice Hall: Pearson Education International.

Hartline, M. D., \& Ferrell, O. C. (1996). The Management of Customer-Contact Service Employees: An Empirical Investigation. Journal of Marketing, 60(4), 52-70. https://doi.org/10.2307/1251901

Ismail, I. (2008). Pengaruh Budaya Organisasi terhadap Kepemimpinan dan Kinerja Karyawan Pemerintah Kabupaten-kabupaten di Madura. Ekuitas, 12(1), 18-36. https://doi.org/10.24034/j25485024.y2008.v12.i1.2057

Jannete, E. T., Rantetampangb, A. L., \& Agus, Z. (2017). The Relation between the Quality of Service and the Level of Satisfaction on Inpatients at Abepura Regional General Hospital. International Journal of Sciences: Basic and Applied Research, 31(3), 255-266. 


\section{I Macrothink}

Human Resource Research

ISSN 1948-5441

2017, Vol. 1, No. 1

Johan, R. (2002). Kepuasan Kerja Karyawan dalam Lingkungan Institusi Pendidikan. Jurnal Pendidikan Penabur, 1(1), 6-31.

Khan, M. R. (2010). The Impact of Organizational Commitment on Employee Job Performance. European Journal of Social Sciences, 15(3), 292-298.

Koesmono, H. T. (2005). Pengaruh Budaya Organisasi terhadap Motivasi dan Kepuasan Kerja serta Kinerja Karyawan pada Sub Sektor Industri Pengolahan Kayu Skala Menengah di Jawa Timur. Jurnal Ekonomi Manajemen, 7(2), 171-188.

Kreitner, Robert dan Angelo Kinichi. (2005). Perilaku Organisasi:Organizational Behavior. Jakarta: Salemba Empat.

Luthans, F. (2006). Perilaku Organisasi. (Edisi 10). Yogyakarta: Penerbit Andi.

Manetje, O., \&Martins, N. (2009). The Relationship between Organizationa Culture and Organizational Commitment. Southern African Business Review, 13(1), 87-111.

Mas'ud,. (2004). Survey Diagnosis Organisasional: Konsep dan Aplikasi. Semarang: Badan Penerbit Undip.

Mathis, R. L., \& John, H. J. (2006). Human Resource Management: Manajemen Sumber Daya Manusia. Edisi 10, Jakarta: Salemba Empat.

McKinnon, J. L. (2003). Organizational Culture: Association with Commitment, Job Satisfaction, Propensity to Remain, and Information Sharing in Taiwan. International Journal of Business Studies, 11(1), 25-44.

Moon, M. J. (2000). Organizational Commitment Revisited in New Public Management: Motivation, Organizational Culture, Sector, and Managerial Level. Public Performance and Management Review, 24(2), 177-194. https://doi.org/10.2307/3381267

Nurjanah. (2008). Pengaruh Gaya Kepemimpinan dan Budaya Organisasi terhadap Komitmen Organisasi dalam Meningkatkan Kinerja Karyawan (Studi pada Biro Lingkup Departemen Pertanian). Tesis Program Pasca Sarjana Magister Manajemen Universitas Diponegoro.

Nurtjahjani, Fullchis dan Masreviastuti. (2007). Analisa Pengaruh Budaya Organisasi terhadap Kepuasan Kerja dan Pengaruhnya pada Kinerja Karyawan. Arthavidya, 8(1), 155-162.

Ojo, O. (2009). Impact Assessment of Corporate Culture on Employee Job Perfromance. Business Intelligence Journal, 2(2), 388-397.

Oluwafemi, E. I. (2017). Understanding Organizational Culture and Organizational Performance: Are They Two Sides of the Same Coin? Journal of Management Research, $9(1)$.

Pavithra, K., \& Kirubadevi, S. (2016). A Study on Performance Analysis of Selected It Companies. International Journal of Commerce and Management Research, 2(1), 18-20. 


\section{I Macrothink}

Praptadi, T. (2009). Analisis Pengaruh Budaya Organisasi dan Pemberdayaan terhadap Komitmen Organisasional dalam Meningkatkan Kinerja Pegawai (Studi pada Pegawai Account Representative di Kantor Pelayanan Pajak (KPP) Pratama Kota Semarang). Tesis Program Pasca Sarjana Magister Manajemen Universitas Diponegoro.

Qureshi, J. A. (2011). Impact of Job Satisfaction and Organizational Commitment on Employee Performance: Evidence from Pakistan. Interdisciplinary Journal of Contemporary Research in Business, 3(4), 642-657.

Robbins, S. P., \& Timothy, A. J. (2008). Perilaku Organisasi. (Edisi 12 Jilid 1 dan 2). Jakarta: Salemba Empat.

Rose, R. C., Naresh, K., \& Ong, G. P. (2009). The Effect of Organizational Learning on Organizational Commitment, Job Satisfaction, and Work Performance. Journal of Applied Business Research, 25(6), 55-65.

Samad, S. (2005). Unraveling the Organizational Commitment and Job Performance Relationship: Exploring the Moderating Effect of Job Satisfaction. The Business Review, 4(2), 79-84.

Samy, S. A. N., Mazen, J. A. S., \& Youssef, M. Abu A. (2016). Measuring Knowledge Management Maturity at HEI to Enhance Performance-An Empirical Study at Al-Azhar University in Palestine. International Journal of Commerce and Management Research, 2(5), $55-62$.

Shore, L. McFarlane, \& Harry, J. M. (1989). Job Satisfaction and Organizational Commitmen in Relation to Work Performance and Turnover Intentions. Human Relations, 42(7), 625-638. https://doi.org/10.1177/001872678904200705

Soedjono. (2005). Pengaruh Budaya Organisasi Terhadap Kinerja Organisasi dan Kepuasan Kerja Karyawan pada Terminal Penumpang Umum di Surabaya. Jurnal Manajemen dan Kewirausahaan, 7(1), 22-47.

Sugiyono. (2010). Metode Penelitian Bisnis: Pendekatan Kuantitatif, Kualitatif, dan R\&D, Bandung: Alfabeta.

Tsui, A. S. (1997). Alternative Approaches to the Employee-Organization Relationship: Does Investment in Employees Pay Off? Academy of Management Journal, 40(5), 1089-1121. https://doi.org/10.2307/256928

Umam, K. (2010). Perilaku Organisasi. Bandung: CV Pustaka Setia.

Wibowo, F. D. (2006). Analisis Pengaruh Peran Kepemimpinan dan Pengembangan Karir terhadap Komitmen Organisasi dalam Meningkatkan Kinerja Karyawan (Studi Kasus PT. Bank Maspion Indonesia Cabang Semarang). Tesis Program Pasca Sarjana Magister Manajemen Universitas Diponegoro.

Widodo, U. (2006). Analisis Pengaruh Gaya Kepemimpinan dan Kepuasan Kerja terhadap Kinerja Bawahan (Studi Empiris pada Perguruan Tinggi Swasta di Kota Semarang). Fokus 
Ekonomi, 1(2), 92-108.

Yiing, L. H., \& Kamarul, Z. B. A. (2009). The Moderating Effects of Organizational Culture on the Relationships between Leadership Behavior and Organizational Commitment and between Organizational Commitment and Job Satisfaction and Performance. Leadership and Organization Development Journal, 30(1), 53-86. https://doi.org/10.1108/01437730910927106

Yousef, D. A. (2002). Job Satisfaction as a Mediator of the Relationship between Role Stressors and Organizational Commitment: A Study from an Arabic Cultural Perspective. Journal of Managerial Psychology, 250-266. https://doi.org/10.1108/02683940210428074

Zain, Z. M., Razanita, I., \& Erlane, K. G. (2009). The Influence of Corporate Culture on Organizational Commitment: A Study on a Malaysian Listed Company. European Journal of Economics, Finance and Administrative Sciences, 17, 16-26.

\section{Copyright Disclaimer}

Copyright for this article is retained by the author(s), with first publication rights granted to the journal.

This is an open-access article distributed under the terms and conditions of the Creative Commons Attribution license (http://creativecommons.org/licenses/by/3.0/). 